\title{
Exposure to Fine Particles by Mine Tailing and Lung Function Effects in a Panel of Schoolchildren, Chañaral, Chile
}

\author{
Karla Yohannessen Vásquez¹, Sergio Alvarado Orellana1,2,3, Stephanie Mesías Monsalve1, \\ José Klarián Vergara4, Claudio Silva Zamora1, Daniella Vidal Muñoz¹, \\ Dante D. Cáceres Lillo ${ }^{1,2 *}$ \\ ${ }^{1}$ Programa de Salud Ambiental, Escuela de Salud Pública, Facultad de Medicina, Universidad de Chile, \\ Santiago de Chile, Chile \\ ${ }^{2}$ Grups de Recerca d'América i AfricaLlatines, Unitat de Bioestadística, Facultat de Medicina, Universitat \\ Autónoma de Barcelona, Barcelona, España \\ ${ }^{3}$ Facultad de Ciencias de la Salud, Universidad de Tarapacá, Arica, Chile \\ ${ }^{4}$ Departamento de Prevención de Riesgos y Medio Ambiente, Universidad Tecnológica Metropolitana, Santiago, \\ Chile \\ Email: karlayohannessen@med.uchile.cl, salvarado@med.uchile.cl, stephaniemesias@med.uchile.cl, \\ jklarian@utem.cl, csilvazamora@gmail.com, daniellavidal@med.uchile.cl, ${ }^{*}$ dcaceres@med.uchile.cl
}

Received 22 January 2015; accepted 6 February 2015; published 11 February 2015

Copyright (C) 2015 by authors and Scientific Research Publishing Inc.

This work is licensed under the Creative Commons Attribution International License (CC BY).

http://creativecommons.org/licenses/by/4.0/

\section{(c) (i) Open Access}

\begin{abstract}
There is much literature on the effects of fine particulate matter $\left(\mathrm{PM}_{2.5}\right)$ on respiratory and cardiovascular health. However, few studies have evaluated the impact of $\mathbf{P M}_{2.5}$ on a population living in the vicinity of a massive deposit of mine tailings. A longitudinal panel study was performed to evaluate the association between exposure to $\mathbf{P M}_{2.5}$ and acute effects on lung function in schoolchildren from November 2012 to May 2013. Ambient levels of $P M_{2.5}$ and its metal composition were measured. Lung function was evaluated using spirometric testing. Associations were quantified using GEE multilevel analysis controlling for confounders by using different lag time periods. The chemical characterization of $\mathrm{PM}_{2.5}$ had high levels of $\mathrm{S}>\mathrm{Na}>\mathrm{Cl}>\mathrm{Ca}>\mathrm{Si}>\mathrm{Fe}>\mathrm{Al}>\mathrm{Mg}>\mathrm{K}>\mathrm{Cu}>$ Ti $>$ and $\mathrm{Zn}$, which would be associated with metals present in tailings. We found a negative association between the temporal variation of $\mathrm{PM}_{2.5}$ and changes in lung function specifically on forced vital capacity. Our results suggest that schoolchildren exposed to fine particulate matter from tailings deposited in the bay of Chañaral have their forced vital capacity decreased, which would affect their present and future lung development, increasing the risk of developing chronic respiratory diseases.
\end{abstract}

*Corresponding author.

How to cite this paper: Yohannessen, K., Alvarado, S., Mesías, S., Klarián, J., Silva, C., Vidal, D. and Cáceres, D.D. (2015) Exposure to Fine Particles by Mine Tailing and Lung Function Effects in a Panel of Schoolchildren, Chañaral, Chile. Journal of Environmental Protection, 6, 118-128. http://dx.doi.org/10.4236/jep.2015.62014 


\section{Keywords}

Mine Tailings, Fine Particulate Matter, Heavy Metals, Lung Function, Schoolchildren

\section{Introduction}

Particulate matter is a complex mixture of solid particles and liquid droplets found in the air, which comes from various natural and anthropogenic sources. This form of pollutant can have different sizes and can be composed of many types of materials and chemicals [1] [2]. Numerous epidemiological studies have found that the exposure to $\mathrm{PM}$, especially the fine fraction $\left(\mathrm{PM}_{2.5}\right)$ has adverse effects on human health, especially for vulnerable populations [1] [3] [4]. Children are more vulnerable than adults to the effects of exposure to polluted air, due to their stage of physical growth, immature immune system, and developing respiratory organs with a more susceptible and reactive respiratory epithelium [3] [5]. Extensive evidence has associated exposure to $\mathrm{PM}_{2.5}$ from vehicular traffic and fuel burning with impaired pulmonary function and increased respiratory complaints on children [3] [4] [6]-[11]. However, few studies have reported on the effects of PM from the soil and dust of mine tailings [12] [13].

Chile is one of the largest copper producers worldwide, and therefore copper is one of the country's major sources of economic income of the country [14]. Most mines are in the central and northern Chile, distributed along the Cordillera de Los Andes. El Salvador is an open-pit mine, located at $2600 \mathrm{~m}$ above sea level (26 $15^{\prime}$ South Lat. S.; $69^{\circ}$ West Long). The chemical composition of this mineral corresponds to cuprous primary porphyry mineralization, which one is characterized by alkali feldspar-biotite-anhydrite-chalcopyrite and bornitechalcopyrite-pyrite mineral assemblages [15]. As a result of the mining operations, between 1939 and 1975, more than $150 \times 10^{6} \mathrm{Mg}$ of tailing were discharged continuously into the Rio Salado without any treatment, being deposited in the bay of Chañaral. This modified the coastline, expanding the area of the beach significantly and causing a heavy siltation and pollution of the bay, directly affecting more than $20 \mathrm{~km}$ of coastline and covering about $12 \mathrm{~km}^{2}$ [16] [17] (Figure 1). This resulted in pollution of tailings sands rich in $\mathrm{Cu}, \mathrm{Fe}, \mathrm{As}, \mathrm{Zn}, \mathrm{Cn}, \mathrm{Pb}, \mathrm{As}$, Hg, Mo and other heavy metals [18] [19]. Coastal winds carry the particulate material contamination over the town of Chañaral. Neary and Garcia-Chevesich report a high incidence of cancers and skin, respiratory, and eye diseases that would be associated with exposure to particulate matter as a result of prevailing coastal winds [17].

The objective of the present study was to evaluate the relationship between lung function and exposure to environmental $\mathrm{PM}_{2.5}$, among a panel of schoolchildren living near a beach highly contaminated with mine tailings.

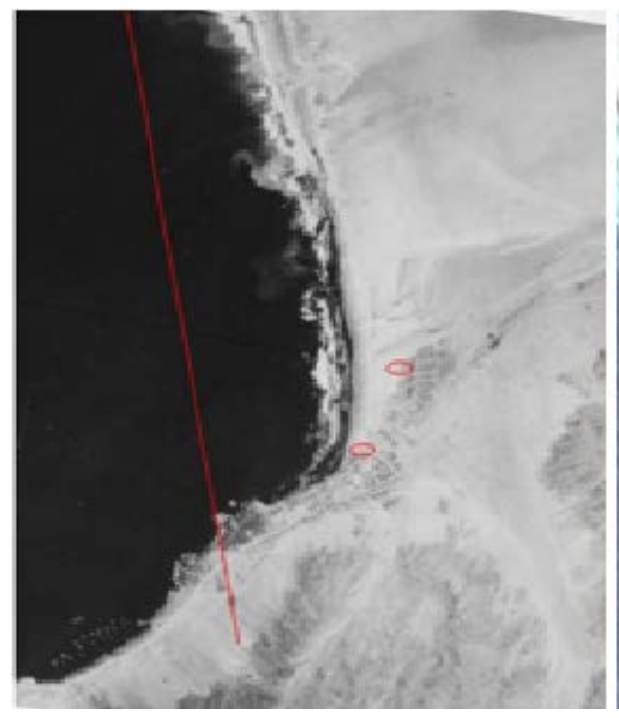

(a)

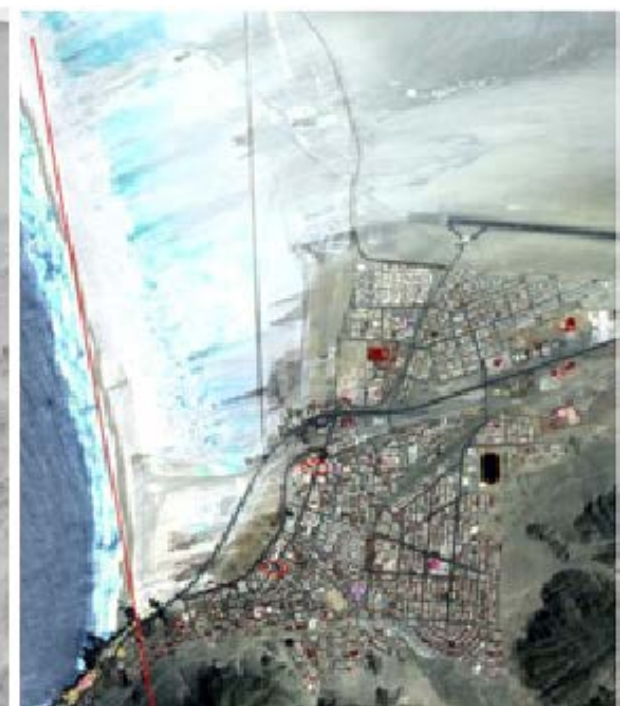

(b)

Figure 1. (a) Oblique photography trimetrogon taken in 1948; (b) SPOT satellite image of 2006. The figure on the left shows the approximate position of the original coast (red line). 


\section{Materials and Methods}

\subsection{Study Design and Location}

A longitudinal panel study was performed using a spatially representative sample of children aged 6 to 15 years residing in Chañaral, Atacama Region, Chile (Figure 2), during the period from November 2012 to May 2013. Chañaral has a surface area of $5772 \mathrm{~km}^{2}$, with a population of 13,543 inhabitants, according to the 2002 census and projected for 2012 is 12,570 inhabitants. The area's main commercial activity is mining, followed by fishing. Geographically, Chañaral has arid desert conditions with scarce rainfall, resulting in sparse vegetation. The local prevailing winds are west to east. The general dryness of the desert environment, combined with the circulation of winds, promotes suspension and transport of dust from the mine tailings towards the valleys [17].

\subsection{Sample Design and Subjects}

The sampling frame for the study was all schoolchildren aged 6 to 15 years attending all elementary schools in the city of Chañaral $(n=1896)$. The estimated sample required was 115 children, assuming an average effect size of $-0.04 \mathrm{~L} / \mathrm{min}$ of decreased lung function for each $1 \mu \mathrm{g} / \mathrm{m}^{3}$ increase in PM concentration, with the significance criterion set at $5 \%$ and a statistical power of $80 \%$ [20]. The sample size was increased by $20 \%$ to adjust for attrition. Therefore, the final estimated sample size was $n=158$.

To ensure spatial representativeness, we used a stratified sampling design based on Neyman's optimal allocation, with 3 strata according to the perpendicular distance of a child's house from the beach (Figure 3). Schoolchildren were selected within these strata by systematic random sampling.

\subsection{Data Collection}

Sociodemographic and health variables. After signing the informed consent document, the parent or legal guardian of the participant responded to a questionnaire to collect the sociodemographic data, health history, and information about environmental pollutant exposure in the household [21].

Particulate matter and meteorological variables. PM levels were measured for 182 days by a certified company (CESMEC S.A) using a monitoring station with adequate coverage of the target area, located in the city of Chañaral (Latitude 26 $20^{\prime} 17.54 " \mathrm{~S}$ Longitude 70³6'57.58"O) (Figure 3). TERMO ${ }^{\circledR}$ 5014i equipment for mea-

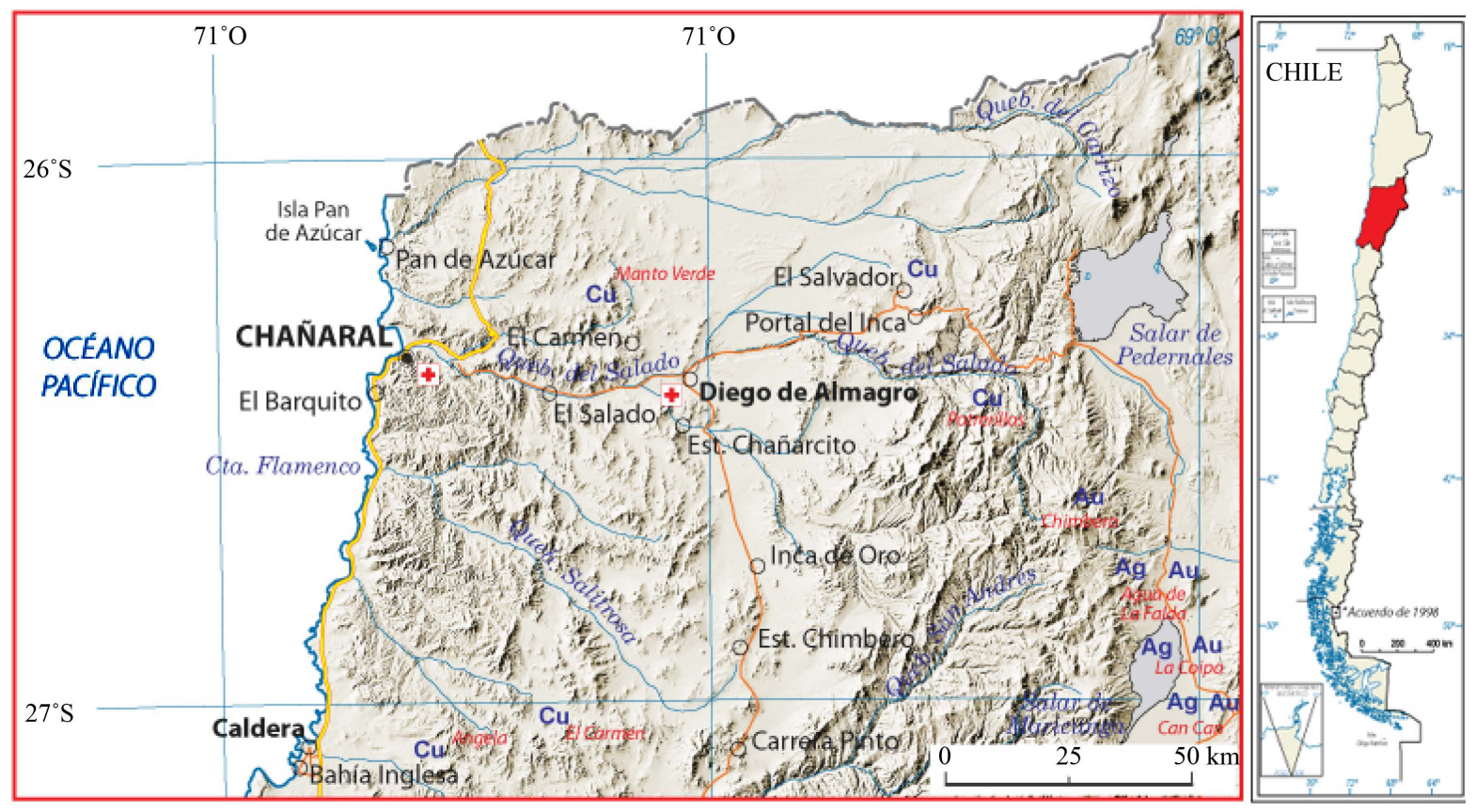

Figure 2. Map of Chile and Chañaral, Atacama region. Source: Adapted of geographic atlas of Chile and the world, Ed. Vicens Vives, Santiago 2009. 


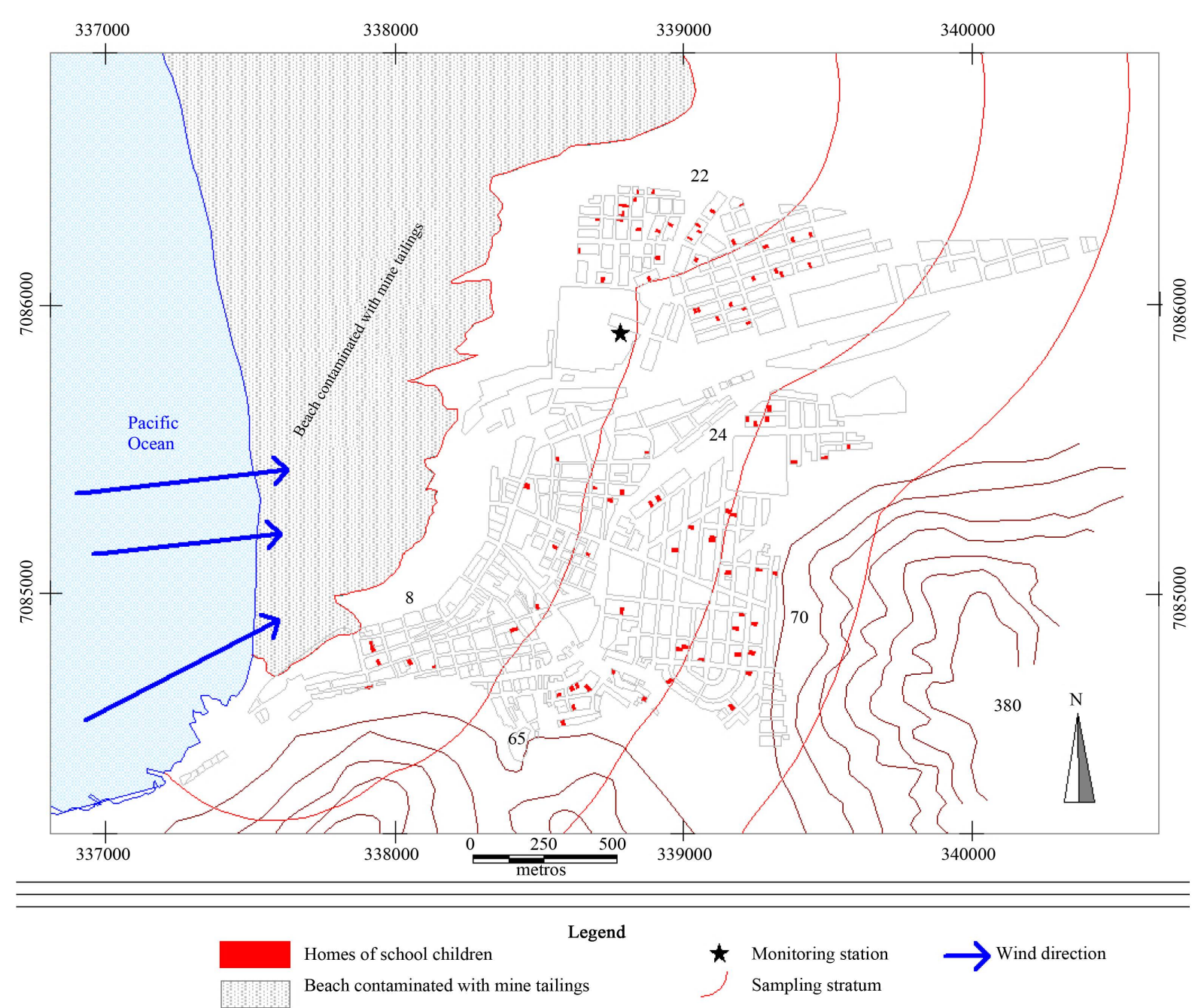

Figure 3. Dividing lines of the strata and location of households of schoolchildren participating and the monitoring station, Chañaral, Atacama Region, Chile 2012-2013.

suring $\mathrm{PM}_{2.5}$ was used. Furthermore, a meteorological station at the same location was used to record wind velocity, temperature, relative humidity, solar radiation, barometric pressure, and precipitation. The concentration of metals in $\mathrm{PM}_{2.5}$ filters was determined with X-ray Florescence XRF an EPA approved methods [22].

Lung function. The children underwent spirometry testing during the school day (morning) at their respective schools, approximately every 2 weeks, from November 12, 2012 to May 10, 2013. Personnel were trained according to the international norms issued by the American Thoracic Society (ATS) guidelines [23], translated and adapted by the Chilean Society of Respiratory Diseases in 2006 [24]. A portable Easy One Spirometer ${ }^{\circledR}$ was used for the measurements. Forced vital capacity maneuvers were performed. Spirometric curves that met ATS acceptability and reproducibility criteria were selected for analysis [24]. At least 3 maneuvers were performed. If the first 3 maneuvers did not meet acceptability and reproducibility criteria, up to 8 maneuvers were performed. Forced expiratory volume in 1 second $\left(\mathrm{FEV}_{1}\right)$, forced vital capacity (FVC), peak expiratory flow (PEF), and forced expiratory flow during the middle portion of the FVC $\left(\mathrm{FEF}_{25-75}\right)$ were recorded.

Anthropometric measurements: Were carried out two weeks before began the functional lung measurements by trained personnel. In this occasion, schoolchildren participated in training for the lung function testing.

\subsection{Statistical Analysis}

Descriptive and exploratory analyses were performed on the database. The relationships between the variables 
were examined using correlations, scatter plots, and box plots. PM concentration levels throughout the study period were analyzed, and lags were established to study its effect on the lung function at time 0 (lag0) as well as the effect of the average, $75^{\text {th }}$ percentile, and maximum values for the 4, 12, and 24 hours prior to the test (lag4 avg, lag12 avg, lag24 avg, lag4 P75, lag12 P75, lag24 P75, lag4 max, lag12 max, lag24 max). Associations between PM and lung function values were studied using a multi-level model of repeated measures nested within schoolchildren, we used Generalized Estimating Equations (GEE) [25] with an unadjusted and adjusted analyses. Analyses were performed using the STATA 11.1 program.

\subsection{Ethical Issues}

This study was approved by the Ethic Committee for Human Research from the Faculty of Medicine at the University of Chile and funded by the Chilean National Fund for Research and Development in Health (CONICYTFONIS: N SA11|2244).

\section{Results}

We invited 158 children (and their parents) to participate, via meetings to provide information about the study’s purpose and participation requirements. We were able to recruit 119 children, 9 of whom (7.5\%) abandoned the study, of which 6 did so before completing the questionnaire, and 3 before starting the measurements. Therefore, 110 children were followed. Figure 3 shows the location of the homes of the participating schoolschildren. The anthropometric and sociodemographic data for the 110 participants are shown in Table 1 . The majority of children were male $(58.18 \%)$, and average age at recruitment was 11.2 years $(\mathrm{SD}=2.7)$. The anthropometric variables showed similar distributions for both sexes, with no significant differences. For both the mother and the father of the children, the most common education level category was 9 to 12 years (58.18\% and 48.18\%, respectively), followed by the category 8 or fewer years of education. Smoking prevalence of at the time of the questionnaire was similar for the father and mother of the child. Asthma and rhinitis prevalence was 9.1\%, and $10.9 \%$, respectively.

The spirometry values for the children are presented in Table 2. Spirometry values increased progressively with age's groups; there were significant differences for all spirometry values between age groups, as well as between sexes. There were no significant differences between groups according to asthma and rhinitis diagnosis, education level or smoking status of parents.

Table 3 shows the average levels by minute as well as the 24-hour average for the PM and meteorological variables during the study period. The $\mathrm{PM}_{2.5}$ levels by minute showed a range of 0.01 to $172.5 \mu \mathrm{g} / \mathrm{m}^{3}$. The meteorological variables showed narrower ranges of variability. There were no extreme temperatures recorded during the study period; furthermore, the relative humidity and barometric pressure were relatively stable and showed no relationship with PM variation. Figure 4 displays a time series for the 24-hour average (daily) $\mathrm{PM}_{2.5}$ concentrations and wind velocities as well as the $25^{\text {th }}$ and $75^{\text {th }}$ percentiles $(\mathrm{P} 25, \mathrm{P} 75)$ of the daily measurements for these variables throughout the study period, along with Chilean norms for 24-hour average $\mathrm{PM}_{2.5} \mathrm{Concentra-}$ tion. As shown, the variability of the wind velocity was higher during the first 3 months of the study, corresponding with the higher PM levels recorded for the same period. The 24-hour average of $\mathrm{PM}_{2.5}$ exceeded the Chilean norm of $50 \mu \mathrm{g} / \mathrm{m}^{3}$ only one occasion.

The chemical composition of the environmental $\mathrm{PM}_{10}$ in Chañaral during the study period was analyzed as part of another study, and therefore we will not go into detail here regarding the procedures and analyses performed to determine these values. Briefly, the average concentrations of metals and metalloids found in the $\mathrm{PM}_{10}$ in Chañaral were, in descending order: $\mathrm{Cl}>\mathrm{Si}>\mathrm{S}>\mathrm{Ca}>\mathrm{Al}>\mathrm{Fe}>\mathrm{K}>\mathrm{Cu}>\mathrm{Mg}>\mathrm{Ti}>\mathrm{Zn}$; comparatively, these average levels are higher than those reported in other studies carried out in the central and northern zones of Chile [26] [27]. On the other hand, to $\mathrm{PM}_{2.5}$ the descending order were $\mathrm{S}>\mathrm{Na}>\mathrm{Cl}>\mathrm{Ca}>\mathrm{Si}>\mathrm{Fe}>$ $\mathrm{Al}>\mathrm{Mg}>\mathrm{K}>\mathrm{Cu}>\mathrm{Ti}>$ and $\mathrm{Zn}$.

Table 4 shows the regression coefficients and 95\% confidence intervals for the average associations between $\mathrm{PM}_{2.5}$ concentration and lung function in GEE models. We fitted this model including only 105 schoolchildren because 5 subjects abandoned the study during the first weeks of follow-up. There were significant negative associations between $\mathrm{PM}_{2.5}$ levels and the lung function variables analyzed. The regression coefficients represent the average decrease in lung function values for a 1-unit increase in $\mathrm{PM}_{2.5}$ concentration. In the unadjusted model, lag12 max $\mathrm{PM}_{2.5}$ concentration was negatively associated with decreased $\mathrm{FEV}_{1}(\beta-0.75 \mathrm{ml}, 95 \% \mathrm{CI}-1.4$, 
Table 1. Anthropometric and sociodemographic characteristics of the schoolchildren studied. Chañaral, Atacama region, Chile, 2012-2013.

\begin{tabular}{|c|c|c|}
\hline Anthropometric Measures & Average & SD \\
\hline Age, years & 11.2 & 2.7 \\
\hline Height, cm & 144.2 & 15.5 \\
\hline Weight, kg & 44.4 & 13.2 \\
\hline Body Mass Index (BMI) & 20.9 & 3.5 \\
\hline Sociodemographic Characteristics & $\mathbf{n}$ & $\%$ \\
\hline Male & 64 & 58.18 \\
\hline $\begin{array}{c}\text { Mother's education level } \\
8 \text { years or less } \\
9 \text { to } 12 \text { years } \\
13 \text { years or more } \\
\text { Don't know/no answer }\end{array}$ & $\begin{array}{l}20 \\
64 \\
13 \\
13\end{array}$ & $\begin{array}{l}18.18 \\
58.18 \\
11.82 \\
11.82\end{array}$ \\
\hline $\begin{array}{c}\text { Father's education level } \\
8 \text { years or less } \\
9 \text { to } 12 \text { years } \\
13 \text { years or more } \\
\text { No answer }\end{array}$ & $\begin{array}{l}23 \\
53 \\
17 \\
17\end{array}$ & $\begin{array}{l}20.91 \\
48.18 \\
15.45 \\
15.45\end{array}$ \\
\hline $\begin{array}{l}\text { Smoking status of mother } \\
\text { Never smoked } \\
\text { Current smoker } \\
\text { Ex-smoker } \\
\text { Don't know/no answer }\end{array}$ & $\begin{array}{l}36 \\
36 \\
25 \\
13\end{array}$ & $\begin{array}{l}32.73 \\
32.73 \\
22.72 \\
11.82\end{array}$ \\
\hline $\begin{array}{c}\text { Smoking status of father } \\
\text { Never smoked } \\
\text { Current smoker } \\
\text { Ex-smoker } \\
\text { Don’t know/no answer }\end{array}$ & $\begin{array}{l}29 \\
40 \\
18 \\
23\end{array}$ & $\begin{array}{l}26.37 \\
36.36 \\
16.36 \\
20.91\end{array}$ \\
\hline $\begin{array}{c}\text { Asthma diagnosis } \\
\text { Yes } \\
\text { No } \\
\text { Don’t know/no answer }\end{array}$ & $\begin{array}{l}10 \\
79 \\
21\end{array}$ & $\begin{array}{r}9.09 \\
71.82 \\
19.09\end{array}$ \\
\hline $\begin{array}{c}\text { Rhinitis diagnosis } \\
\text { Yes } \\
\text { No } \\
\text { Don’t know/no answer }\end{array}$ & $\begin{array}{l}12 \\
79 \\
12\end{array}$ & $\begin{array}{l}10.91 \\
71.82 \\
17.27\end{array}$ \\
\hline $\begin{array}{c}\text { Type of school } \\
\text { Private } \\
\text { Municipal }\end{array}$ & $\begin{array}{c}10 \\
100\end{array}$ & $\begin{array}{c}9.09 \\
90.91\end{array}$ \\
\hline $\begin{array}{c}\text { Strata } \\
\text { Strata } 1(<600 \mathrm{mts}) \\
\text { Strata } 2(600-1200 \mathrm{mts}) \\
\text { Strata } 3(>1200 \mathrm{mts})\end{array}$ & $\begin{array}{c}44 \\
60 \\
6\end{array}$ & $\begin{array}{c}40 \\
54.55 \\
5.45\end{array}$ \\
\hline
\end{tabular}

SD: standard deviation.

-0.03) i.e. for every 1 unit increase in the maximum concentration of 12 hour $\mathrm{PM}_{2.5}$ decreases the $\mathrm{FEV}_{1} 0.75 \mathrm{ml}$ with a confidence interval between -1.4 and $-0.03 \mathrm{ml}$, which it does not include the value of invalidity (0) allows us to conclude the negative association is significant and not due to chance; lag4 and lag12 avg PM $\mathrm{P}_{2.5}$ were also negatively associated with FVC $(\beta-2.42 \mathrm{ml}, 95 \% \mathrm{CI}-4.7,-0.1$; and $\beta-5.07 \mathrm{ml}, 95 \% \mathrm{CI}-8.9$, -1.1 , respectively), as were lag4, lag12, and lag24 max $\mathrm{PM}_{2.5}$ levels $(\beta-1.74 \mathrm{ml}, 95 \% \mathrm{CI}-2.7,-0.8 ; \beta-1.90 \mathrm{ml}, 95 \%$ CI $-2.8,-1.01$; and $\beta-2.01 \mathrm{ml}, 95 \% \mathrm{CI}-2.9,-1.03$, respectively). In the unadjusted analysis, the only flow value showing a significant negative association with PM was PEF, which was negatively associated with lag24 
Table 2. Lung function values of the schoolchildren during the study period. Chañaral, Atacama region, Chile, $2012-2013$.

\begin{tabular}{ccccccc}
\hline & \multirow{2}{*}{$\mathbf{n}^{*}$} & $\mathbf{n}^{* *}$ & $\mathrm{FEV}_{1}(\mathrm{ml})$ & FVC $(\mathrm{ml})$ & PEF $(\mathrm{ml} / \mathrm{sec})$ & $\mathrm{FEF}_{25}-75(\mathrm{ml} / \mathrm{sec})$ \\
\cline { 4 - 7 } & & & Average $(\mathrm{SD})$ & Average $(\mathrm{SD})$ & Average $(\mathrm{SD})$ & Average $(\mathrm{SD})$ \\
\hline 99 years & 28 & 136 & $1706.5(408.01)$ & $2081.8(472.5)$ & $3719.5(1093.3)$ & $1802.8(624.2)$ \\
9 to 11 years & 24 & 113 & $2018.7(402.5)$ & $2385.3(420.0)$ & $4561.3(915.3)$ & $2344.2(768.9)$ \\
11 to 13 years & 22 & 111 & $2378.8(364.7)$ & $2898.04(432.5)$ & $5097.1(1156.1)$ & $2487.6(722.6)$ \\
$>13$ years & 36 & 151 & $3385.4(706.6)$ & $3983.7(916.0)$ & $7012.2(1511.9)$ & $3692.3(934.1)$ \\
$\quad$ Total & 110 & 511 & $2417.7(838.4)$ & $2888.2(984.7)$ & $5177.9(1763.5)$ & $2629.6(1068.3)$ \\
\hline
\end{tabular}

"Number of schoolchildren; *N Number of spirometry tests. SD: standard deviation, $\mathrm{FEV}_{1}(\mathrm{ml})$ : forced expiratory volume during the first second (milliliter), FVC (ml): forced vital capacity (milliliters), PEF (ml/sec): peak expiratory flow (milliliters/seconds), $\mathrm{FEF}_{25}$ - 75 (ml/sec): forced expiratory flow 25 - 75 (milliliters/seconds).

Table 3. Particulate matter and meteorological variables during the study period. Chañaral, Atacama Region, Chile, 2012-2013.

\begin{tabular}{cccccccc}
\hline & $\mathbf{N}$ & Average (SD) & P25 & P50 & P75 & Min - max \\
\hline & \multicolumn{7}{c}{ Measurements during the study period* } \\
\hline $\mathrm{PM}_{2.5}\left(\mu \mathrm{g} / \mathrm{m}^{3}\right)$ & 207,519 & $17.15(15.24)$ & 7.88 & 13.58 & 23.08 & $0.01-172.5$ \\
Temperature $\left({ }^{\circ} \mathrm{C}\right)$ & 260,832 & $18.39(2.71)$ & 16.51 & 18.07 & 20.14 & $10.44-27.35$ \\
Relative humidity (\%) & 260,832 & $70.13(8.93)$ & 63.85 & 71.27 & 77.26 & $34.33-89.9$ \\
Wind velocity (m/s) & 260,832 & $2.59(1.80)$ & 1.10 & 2.19 & 3.93 & $0-10.26$ \\
Barometric pressure (mmHg) & 260,832 & $757.23(1.53)$ & 756.2 & 757.2 & 758.2 & $751.8-762.5$ \\
24-hour average & & & & & & \\
PM $_{2.5}\left(\mu \mathrm{g} / \mathrm{m}^{3}\right)$ & 182 & $13.63(5.86)$ & 10.7 & 12.5 & 14.8 & $4.3-50.1$ \\
\hline
\end{tabular}

"By minute; ${ }^{* *}$ By day. SD: standard deviation. P25: $25^{\text {th }}$ percentile, P50: 50 ${ }^{\text {th }}$ percentile, P75: $75^{\text {th }}$ percentile, min - max: minimum - maximum, PM: particulate matter, $\mu \mathrm{g} / \mathrm{m}^{3}$ : micrograms/cubic meters, ${ }^{\circ} \mathrm{C}$ : degrees Celsius, $\mathrm{m} / \mathrm{s}$ : meters/second, mmHg: millimeters of mercury.

Table 4. Regression coefficients [unadjusted and adjusted] for a 1-unit increase in $\mathrm{PM}_{2.5}$ level (CI 95\%) on lung function values in schoolchildren of Chañaral, Atacama region, Chile, 2012-2013.

\begin{tabular}{|c|c|c|c|c|c|c|c|c|}
\hline & \multicolumn{2}{|c|}{$\mathrm{FEV}_{1}(\mathrm{ml})$} & \multicolumn{2}{|c|}{ FVC (ml) } & \multicolumn{2}{|c|}{ PEF (ml/sec) } & \multicolumn{2}{|c|}{$\mathrm{FEF}_{25-75}(\mathrm{ml} / \mathrm{sec})$} \\
\hline & $\begin{array}{l}\text { Coef }_{\text {unadj }} \\
\text { IC 95\% }\end{array}$ & $\begin{array}{l}\text { Coef }_{\text {adj }}{ }^{*} \\
\text { IC } 95 \%\end{array}$ & $\begin{array}{l}\text { Coefunadj } \\
\text { IC } 95 \%\end{array}$ & $\begin{array}{l}\text { Coef }_{\text {adj }}{ }^{*} \\
\text { IC } 95 \%\end{array}$ & $\begin{array}{l}\text { Coef }_{\text {unadj }} \\
\text { IC } 95 \%\end{array}$ & $\begin{array}{l}\text { Coef }_{\text {adj }}{ }^{*} \\
\text { IC } 95 \%\end{array}$ & $\begin{array}{l}\text { Coef }_{\text {unadj }} \\
\text { IC } 95 \%\end{array}$ & $\begin{array}{l}\text { Coef }_{\text {adj }}{ }^{*} \\
\text { IC } 95 \%\end{array}$ \\
\hline \multicolumn{9}{|c|}{$\mathbf{P M}_{2.5}$} \\
\hline lag0 & $\begin{array}{c}1.08 \\
(-2.3,0.2)\end{array}$ & $\begin{array}{c}-1.22 \\
(-2.5,0.1)\end{array}$ & $\begin{array}{c}-1.63 \\
(-3.4,0.1)\end{array}$ & $\begin{array}{c}-1.77 \\
(-3.6,0.03)\end{array}$ & $\begin{array}{c}-1.67 \\
(-6.2,2.8)\end{array}$ & $\begin{array}{c}-2.19 \\
(-6.7,2.3)\end{array}$ & $\begin{array}{c}-0.55 \\
(-3.9,2.8)\end{array}$ & $\begin{array}{c}-0.72 \\
(-4.1,2.6)\end{array}$ \\
\hline lag4 avg & $\begin{array}{c}-0.79 \\
(-3.0,1.4)\end{array}$ & $\begin{array}{c}-0.38 \\
(-2.6,1.8)\end{array}$ & $\begin{array}{c}-2.42 \\
(-4.7,-0.1)\end{array}$ & $\begin{array}{c}-1.88 \\
(-4.2,0.4)\end{array}$ & $\begin{array}{c}-0.37 \\
(-6.9,6.1)\end{array}$ & $\begin{array}{c}0.66 \\
(-5.8,7.1)\end{array}$ & $\begin{array}{c}2.21 \\
(-2.7,7.1)\end{array}$ & $\begin{array}{c}2.93 \\
(-1.9,7.8)\end{array}$ \\
\hline lag12 avg & $\begin{array}{c}-2.05 \\
(-4.8,0.7)\end{array}$ & $\begin{array}{c}-0.47 \\
(-3.2,2.2)\end{array}$ & $\begin{array}{c}-5.07 \\
(-8.9,-1.1)\end{array}$ & $\begin{array}{c}-3.47 \\
(-7.2,0.2)\end{array}$ & $\begin{array}{c}-1.30 \\
(-10.2,7.6)\end{array}$ & $\begin{array}{c}1.95 \\
(-7.3,11.2)\end{array}$ & $\begin{array}{c}5.13 \\
(-1.8,12.1)\end{array}$ & $\begin{array}{c}7.71 \\
(-0.1,15.2)\end{array}$ \\
\hline lag24 avg & $\begin{array}{c}0.30 \\
(-1.9,2.5)\end{array}$ & $\begin{array}{c}-0.77 \\
(-3.1,1.6)\end{array}$ & $\begin{array}{c}-0.85 \\
(-3.7,2.1)\end{array}$ & $\begin{array}{c}-2.71 \\
(-6.3,0.9)\end{array}$ & $\begin{array}{c}3.79 \\
(-4.2,11.8)\end{array}$ & $\begin{array}{c}2.35 \\
(-6.5,11.2)\end{array}$ & $\begin{array}{c}2.73 \\
(-2.4,7.9)\end{array}$ & $\begin{array}{c}3.41 \\
(-2.0,8.8)\end{array}$ \\
\hline lag4 P75 & $\begin{array}{c}0.07 \\
(-1.4,1.5)\end{array}$ & $\begin{array}{c}0.86 \\
(-0.6,2.3)\end{array}$ & $\begin{array}{c}-1.07 \\
(-2.6,0.5)\end{array}$ & $\begin{array}{c}-0.14 \\
(-1.6,1.3)\end{array}$ & $\begin{array}{c}-2.25 \\
(-7.4,2.9)\end{array}$ & $\begin{array}{c}-0.32 \\
(-5.3,4.7)\end{array}$ & $\begin{array}{c}2.96 \\
(-0.7,6.6)\end{array}$ & $\begin{array}{c}3.92 \\
(-0.2,7.6)\end{array}$ \\
\hline lag12 P75 & $\begin{array}{c}0.51 \\
(-2.4,3.4)\end{array}$ & $\begin{array}{c}2.06 \\
(-0.8,4.9)\end{array}$ & $\begin{array}{c}0.01 \\
(-3.3,3.3)\end{array}$ & $\begin{array}{c}1.87 \\
(-1.5,5.2)\end{array}$ & $\begin{array}{c}-0.44 \\
(-10.3,9.3)\end{array}$ & $\begin{array}{c}3.67 \\
(-6.1,13.4)\end{array}$ & $\begin{array}{c}4.47 \\
(-2.5,11.4)\end{array}$ & $\begin{array}{c}6.25 \\
(-0.8,13.3)\end{array}$ \\
\hline lag24 P75 & $\begin{array}{c}0.14 \\
(-3.6,3.9)\end{array}$ & $\begin{array}{c}0.52 \\
(-3.5,4.6)\end{array}$ & $\begin{array}{c}1.91 \\
(-3.1,6.8)\end{array}$ & $\begin{array}{c}2.33 \\
(-2.7,7.4)\end{array}$ & $\begin{array}{c}-4.36 \\
(-16.8,8.1)\end{array}$ & $\begin{array}{c}-3.16 \\
(-15.8,9.5)\end{array}$ & $\begin{array}{c}2.04 \\
(-7.8,11.9)\end{array}$ & $\begin{array}{c}3.49 \\
(-7.1,14.1)\end{array}$ \\
\hline lag4 max & $\begin{array}{c}-0.66 \\
(-1.5,0.2)\end{array}$ & $\begin{array}{c}0.14 \\
(-0.8,1.1)\end{array}$ & $\begin{array}{c}-1.74 \\
(-2.7,-0.8)\end{array}$ & $\begin{array}{c}-0.81 \\
(-1.7,0.2)\end{array}$ & $\begin{array}{c}-1.98 \\
(-5.1,1.1)\end{array}$ & $\begin{array}{c}0.06 \\
(-3.1,3.2)\end{array}$ & $\begin{array}{c}1.09 \\
(-1.3,3.5)\end{array}$ & $\begin{array}{c}-2.24 \\
(-0.2,4.6)\end{array}$ \\
\hline $\operatorname{lag} 12$ max & $\begin{array}{c}-0.75 \\
(-1.4,-0.03)\end{array}$ & $\begin{array}{c}0.13 \\
(-0.6,0.8)\end{array}$ & $\begin{array}{c}-1.90 \\
(-2.8,-1.01)\end{array}$ & $\begin{array}{c}-0.96 \\
(-1.8,-0.1)\end{array}$ & $\begin{array}{c}-2.61 \\
(-5.3,0.1)\end{array}$ & $\begin{array}{c}-0.51 \\
(-3.2,2.1)\end{array}$ & $\begin{array}{c}1.63 \\
(-0.4,3.6)\end{array}$ & $\begin{array}{c}2.89 \\
(-0.7,5.0)\end{array}$ \\
\hline lag24 max & $\begin{array}{c}-0.72 \\
(-1.5,0.1)\end{array}$ & $\begin{array}{c}0.16 \\
(-0.7,1.1)\end{array}$ & $\begin{array}{c}-2.01 \\
(-2.9,-1.03)\end{array}$ & $\begin{array}{c}-1.19 \\
(-2.3,-0.1)\end{array}$ & $\begin{array}{c}-2.93 \\
(-5.7,-0.1)\end{array}$ & $\begin{array}{c}-0.96 \\
(-3.8,1.9)\end{array}$ & $\begin{array}{c}1.86 \\
(-0.3,4.0)\end{array}$ & $\begin{array}{c}3.47 \\
(-1.2,5.7)\end{array}$ \\
\hline
\end{tabular}

*GEE model adjusted for age, sex, weight, wind speed, ambient temperature; Significant values in bold. $\mathrm{FEV}_{1}(\mathrm{ml})$ : forced expiratory volume in one second (ml), FVC (ml): forced vital capacity (milliliters), PEF (mL/sec): peak expiratory flow (milliliters/second), $\mathrm{FEF}_{25}-75$ ( $\mathrm{mL}^{\mathrm{sec}}$ ): forced expira-

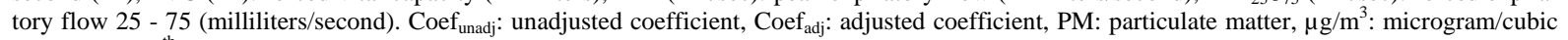
meter, P75: $75^{\text {th }}$ percentile. 

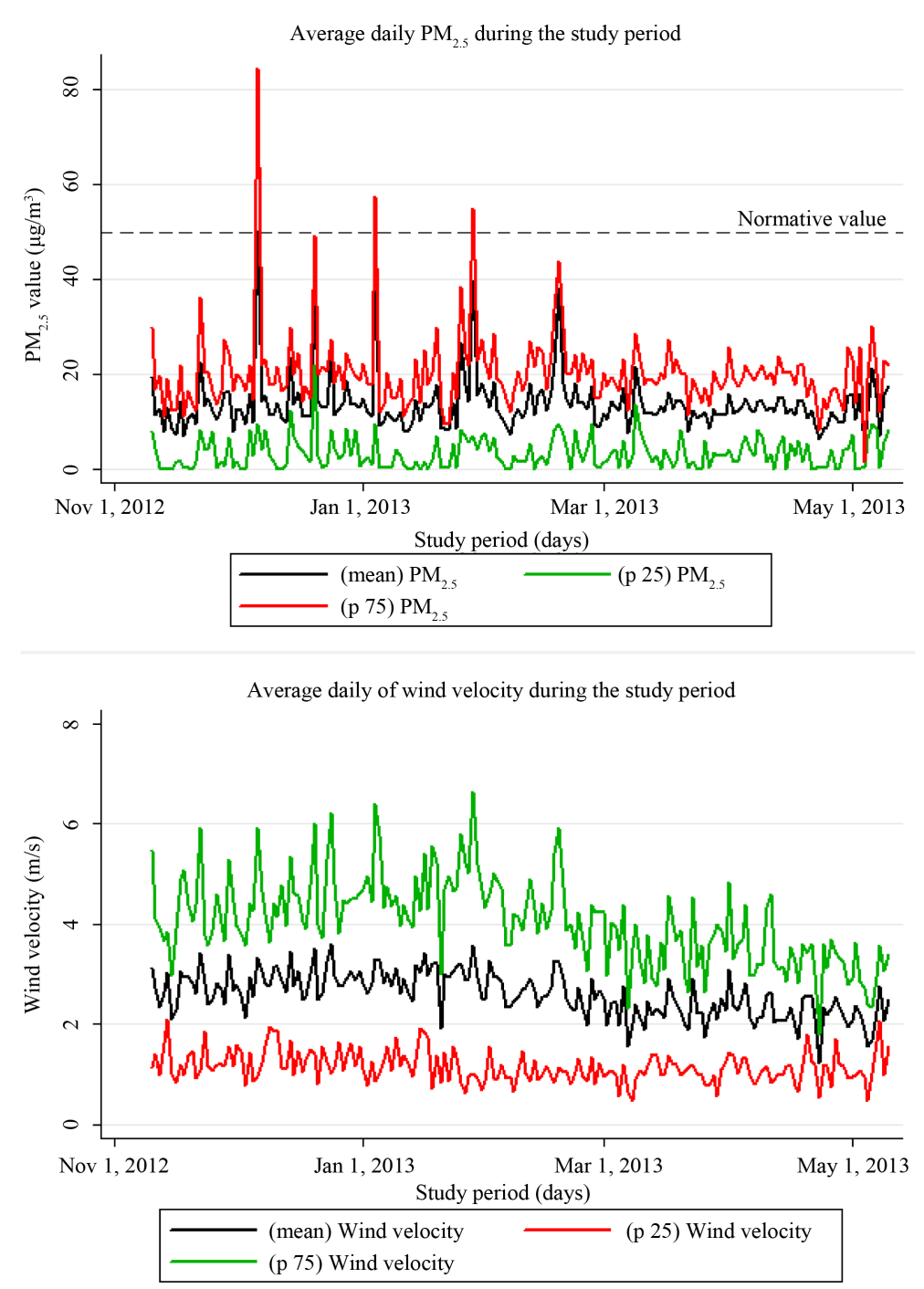

Figure 4. Descriptive time series showing 24-hour $\mathrm{PM}_{2.5}$, and wind velocity values during the study period. Chañaral, Atacama region, Chile, 2012-2013.

max $\mathrm{PM}_{2.5}$ concentration $(\beta-2.93 \mathrm{ml} / \mathrm{sec}, 95 \% \mathrm{CI}-5.7,-0.1)$. After adjusting for age, sex, weight, environmental temperature, and wind speed, only the negative associations between lag12 max and lag24 max $\mathrm{PM}_{2.5}$ levels and FVC remained significant. Non-significant relationship with lung function was observed when we fitted a model considering the distance of households of schoolchildren to tailings deposit (as a continuous variable and according to categories of strata), the diagnosis of asthma and rhinitis as well as parental smoking were considered (data not shown).

\section{Discussion}

In order to study the short-term effect of environmental exposure to PM on lung function values, we found a negative association between environmental exposure to PM and spirometry values, in an urban population of schoolchildren living near a beach contaminated with mine tailings. This decrease in lung function was especially marked for FVC impairment associated with fine particulate matter exposure $\left(\mathrm{PM}_{2.5}\right)$.

In other studies with similar panel designs, the PM value most commonly reported has been the median of 24-h average concentrations during the period studied. For $\mathrm{PM}_{2.5}$, the median 24-h concentration in this study $\left(12.5 \mu \mathrm{g} / \mathrm{m}^{3}\right)$ moderately exceeded the value reported by Trenga et al. [11] at $11.2 \mu \mathrm{g} / \mathrm{m}^{3}$ for a residential area in Seattle, United States and markedly exceeded the value reported by Dales et al. at $6.5 \mu \mathrm{g} / \mathrm{m}^{3}$ for an area affected 
by heavy truck traffic in Windsor, Canada [8]; however, a study performed by Moshammer et al. in a zone exposed to industrial pollution and vehicular traffic in Linz, Austria [6] reported a median value of $15.79 \mu \mathrm{g} / \mathrm{m}^{3}$, exceeding the value reported in the present study.

Due to the controversy of suggesting that central site measurements may not be representative of individual or residential community exposure, Trenga et al. studied the differences between concentrations measured in the central site and those measured immediately outside personal residences. The author found a strong correlation between the two values $(r=0.77)$ [11]. This finding is very important, as most studies on the health effects of air pollution rely on central site measurements, including the present study.

The average metal and metalloid concentrations found in the $\mathrm{PM}_{10}$ in Chañaral were generally greater than those reported by other studies in different cities and mining zones in northern Chile and are consistent with the metal measured for this population in different studies [17] [18] [26] [28]. Several studies in animal models suggest that the bioavailable metal transition is one the primary determinants of the acute inflammatory response for both the combustion source and ambient PM samples [2] [29]-[31]. Genotoxic and epigenotoxic effects on human bronchial epithelial cells have been reported due to variable concentrations of transition metals and organic compounds [32] [33].

Pulmonary development, immune function, and respiratory response to various air pollutants are interrelated via complex multifactorial processes [34], possibly explaining the high degree of variability for lung function values reported.

The results of the association analysis for PM and lung function are largely consistent with the literature. However, the type of measure reported varies by study. Some authors have reported changes in lung function for each $10 \mu \mathrm{g} / \mathrm{m}^{3}$ of change in PM or change in interquartile range (IQR) of PM, while other authors have focused on variations in spirometry values as compared to predicted values. Furthermore, the time lags used vary among studies, making it difficult to compare results. $\mathrm{PM}_{2.5}$ was negatively associated with $\mathrm{FEF}_{25}-75$ in the study by Trenga et al., carried out on children with asthma, and with $\mathrm{FEV}_{1}$ and PEF in the study by Moshammer et al., carried out on healthy children in Linz, Austria. Dales et al. only studied $\mathrm{FEV}_{1}$ values in asthmatic children, finding a negative association with 12-h lag $\mathrm{PM}_{2.5}$ concentration. In our study, we found negative unadjusted associations between $\mathrm{FEV}_{1}$ and 12-h lag maximum $\mathrm{PM}_{2.5}$ concentration and between PEF and 24-h lag maximum $\mathrm{PM}_{2.5}$ concentration, which is consistent with the findings reported by Moshammer et al. in healthy children. The same authors also found a marked association between average and maximum 4 and 12-h lag $\mathrm{PM}_{2.5}$ levels with FVC as well as 24-h lag maximum levels with FVC.

Most of the significant associations found with $\mathrm{PM}_{2.5}$ levels were for FVC. This measure is the maximum capacity of air expelled during a forced expiration and represents a concrete indicator of pulmonary capacity. Decreased FVC indicates a restrictive ventilatory defect. One of the causes described in the literature for this type of limitation is inhalation of organic and inorganic dust. However, the findings in this study represent acute variation in FVC rather than a progressive decrease in function over time. To confirm the long-term effects of exposure, it would be necessary to extend the study to follow the children for several more years. The sample of schoolchildren studied was mostly healthy, and the associations between PM concentration and lung function did not vary according to asthma or rhinitis diagnosis; that is, exposure to increased $\mathrm{PM}_{2.5}$ levels impairs respiratory function in the short-term regardless of asthma or rhinitis diagnosis.

While changes in lung function as a result of chronic exposure become evident at more advanced ages, the fact that we found associations between short-term $\mathrm{PM}_{2.5}$ exposure and lung function indicates that schoolchildren in Chañaral are currently affected by the exposure. Further chronic effects may emerge during adulthood. Moreover, given that the $\mathrm{PM}_{2.5}$ studied contained metallic particles, long-term exposure may have other silent and cumulative effects not only on the respiratory system but also on other organs due to bio-accumulation of heavy metals.

These findings underscore the need for further studies in communities exposed to air pollution from various sources in order to uncover other acute or chronic effects of exposure to pollution from mine tailings.

\section{Conclusion}

The present study is the first report of the respiratory health effects of exposure to PM from mine tailings among the inhabitants of Chañaral. Increased $\mathrm{PM}_{2.5}$ levels associated with toxic metals affect the respiratory function of schoolchildren living in the city and the variation in FVC suggests that these children may be vulnerable to ef- 
fects of long-term exposure. Measures to control or decrease exposure in this population are needed, and we hope that the evidence reported here will contribute to such efforts.

\section{Acknowledgements}

The authors would like to thank the schoolchildren who took part in the study as well as their parents; authorities in the departments of education, environment, and community health for the Municipality of Chañaral; the staff who carried out the fieldwork; Dr. Benigno Linares for his assistance in the questionnaire's design; and the Chilean National Fund for Research and Development in Health (FONIS N SA11|2244).

\section{Conflicts of Interest}

The authors declare that they have no conflicts of interest.

\section{References}

[1] Franck, U., Tuch, T., Manjarrez, M., Wiedensohler, A. and Herbarth, O. (2006) Indoor and Outdoor Submicrometer Particles: Exposure and Epidemiologic Relevance (“The 3 Indoor Ls”). Environmental Toxicology, 21, 606-613. http://dx.doi.org/10.1002/tox.20224

[2] Antonini, J., Taylor, M., Leonard, S., Lawryk, N., Shi, X., Clarke, R. and Roberts, J. (2004) Metal Composition and Solubility Determine Lung Toxicity Induced by Residual Oil Fly Ash Collected from Different Sites within a Power Plant. Molecular and Cellular Biochemistry, 255, 257-265. http://dx.doi.org/10.1023/B:MCBI.0000007281.32126.2c

[3] Li, S., Williams, G., Jalaudin, B. and Baker, P. (2012) Panel Studies of Air Pollution on Children's Lung Function and Respiratory Symptoms: A Literature Review. Journal of Asthma, 49, 895-910. http://dx.doi.org/10.3109/02770903.2012.724129

[4] Ward, D. and Ayres, J. (2004) Particulate Air Pollution and Panel Studies in Children: A Systematic Review. Occupational and Environmental Medicine, 61, 1-12. http://dx.doi.org/10.1136/oem.2003.007088

[5] Lee, Y. and Dong, G. (2012) Air Pollution and Health Effects in Children. In: Khare, M., Ed., Air Pollution-Monitoring Modelling and Health, InTech, 337-356.

[6] Moshammer, H., Hutter, H.-P., Hauck, H. and Neuberger, M. (2006) Low Levels of Air Pollution Induce Changes of Lung Function in a Panel of Schoolchildren. European Respiratory Journal, 27, 1138-1143. http://dx.doi.org/10.1183/09031936.06.00089605

[7] Chang, Y., Wua, C., Lee, L., Lin, R., Yu, Y. and Chen, Y. (2012) The Short-Term Effects of Air Pollution on Adolescent Lung Function in Taiwan. Chemosphere, 87, 26-30. http://dx.doi.org/10.1016/j.chemosphere.2011.11.048

[8] Dales, R., Chen, L., Frescura, A.M., Liu, L. and Villeneuve, P.J. (2009) Acute Effects of Outdoor Air Pollution on Forced Expiratory Volume in 1 s: A Panel Study of Schoolchildren with astHma. European Respiratory Journal, 34, 316-323. http://dx.doi.org/10.1183/09031936.00138908

[9] Gent, J., Koutrakis, P., Belanger, K., Triche, E., Holford, T., Bracken, M. and Leaderer, B. (2009) Symptoms and Medication Use in Children with Asthma and Traffic-Related Sources of Fine Particle Pollution. Environmental Health Perspectives, 117, 1168-1174.

[10] Min, J.-Y., Min, K.-B., Cho, S.-I. and Paek, D. (2008) Lag Effect of Particulate Air Pollution on Lung Function in Children. Pediatric Pulmonology, 43, 476-480. http://dx.doi.org/10.1002/ppul.20800

[11] Trenga, C., Sullivan, J., Schildcrout, J., Shepherd, K., Shapiro, G., Liu, L., Kaufman, J. and Koenig, J. (2006) Effect of Particulate Air Pollution on Lung Function in Adult and Pediatric Subjects in a Seattle Panel Study. Chest, 129, 16141622. http://dx.doi.org/10.1378/chest.129.6.1614

[12] Hong, Y.C., Pan, X.C., Kim, S.Y., Park, K., Park, E.J., Jin, X., Yi, S.M., Kim, Y.H., Park, C.H., Song, S., et al. (2010) Asian Dust Storm and Pulmonary Function of School Children in Seoul. Science of the Total Environment, 408, 754759. http://dx.doi.org/10.1016/j.scitotenv.2009.11.015

[13] Csavina, J., Field, J., Taylor, M., Gao, S., Landázuri, A., Betterton, E. and Sáez, A.E. (2012) A Review on the Importance of Metals and Metalloids in Atmospheric Dust and Aerosol from Mining Operations. Science of the Total Environment, 433, 58-73. http://dx.doi.org/10.1016/j.scitotenv.2012.06.013

[14] Instituto Nacional de Estadísticas (INE) (2008) Minería: La actividad exportadora más importante de Chile.

[15] Gustapfson, L.B. and Hunt, J.P. (1975) The Porphyry Copper Deposit at El Salvador, Chile. Economic Geology, 70, 857-912.

[16] Vergara, A. (2011) “Cuando el rio suena, piedras trae”: Relaves de cobre en la bahía de Chañaral, 1938-1990. Cua- 
dernos de Historia 35, Departamento de Ciencias Históricas, Universidad de Chile, 135-151.

[17] Neary, D. and Garcia-Chevesich, P. (2008) Hydrology and Erosion Impacts of Mining Derived Coastal Sand Dunes, Chanaral Bay, Chile. Hydrology and Water Resources in Arizona and the Southwest, 38, 47-52.

[18] Castilla, J.C. (1983) Environmental Impacts in Sandy Beaches of Copper Mine Tailing at Chañaral, Chile. Marine Pollution Bulletin, 14, 159-464.

[19] Paskoff, R. and Petiot, R. (1990) Coastal Progradation as a By-Product of Human Activity: An Example from Chañaral Bay, Atacama Desert, Chile. Journal of Coastal Research, 6, 91-102.

[20] Sánchez, J., Romieu, I., Ruiz, S., Pino, P. and Gutiérrez, M. (1999) Efectos agudos de las partículas respirables y del dióxido de azufre sobre la salud respiratoria en niños del área industrial de Puchuncaví, Chile. Revista Panamericana de Salud Pública, 6, 384-381. http://dx.doi.org/10.1590/S1020-49891999001100003

[21] Linares, B., Guizar, J., Amador, N., Garci, A., Miranda, V., Perez, J. and Chapela, R. (2010) Impact of Air Pollution on Pulmonary Function and Respiratory Symptoms in Children. Longitudinal Repeated-Measures Study. BMC Pulmonary Medicine, 10.

[22] U.S. Environmental Protection Agency (1997) Compendium Method IO-3.3 Determination of Metals in Ambient Particulate Matter Using X-Ray Fluorescence (XRF) Spectroscopy. Center for Environmental Research Information Office of Research and Development, Cincinnati.

[23] Miller, M.R., Crapo, R., Hankinson, J., Brusasco, V., Burgos, F., Casaburi, R., Coates, A., Enright, P., Van de Grinten, C.P.M., Gustafsson, P., et al. (2005) General Considerations for Lung Function Testing. European Respiratory Journal, 26, 153-161. http://dx.doi.org/10.1183/09031936.05.00034505

[24] Gutiérrez, C.-M., Beroiza, T., Borzone, G., Caviedes, I., Céspedes, G., Gutiérrez, N.-M., Moreno, R., Oyarzún, M., Palacios, S. and Schonffeldt, P. (2007) Espirometría: Manual de procedimientos. Sociedad Chilena de Enfermedades Respiratorias, 2006. Revista Chilena de Enfermedades Respirator, 23, 31-42.

[25] Hardin, J. and Hilbe, J. (2003) Generalized Estimating Equations. Editorial Chapman \& Hall/CRC.

[26] Jorquera, H. and Barraza, F. (2013) Source Apportionment of PM10 and PM2.5 in a Desert Region in Northern Chile. Science of the Total Environment, 444, 327-335. http://dx.doi.org/10.1016/j.scitotenv.2012.12.007

[27] Gidhagen, L., Kahelin, H., Schmidt-Thomé, P. and Johansson, C. (2002) Anthropogenic and Natural Levels of Arsenic in PM10 in Central and Northern Chile. Atmospheric Environment, 36, 3803-3817. http://dx.doi.org/10.1016/S1352-2310(02)00284-4

[28] Kavouras, I., Koutrakis, P., Cereceda-Balic, F. and Oyola, P. (2001) Source Apportionment of PM10 and PM2.5 in Five Chilean Cities Using Factor Analysis. Journal of the Air \& Waste Management Association, 51, 451-464. http://dx.doi.org/10.1080/10473289.2001.10464273

[29] Costa, D.-L. and Dreher, K.-L. (1997) Bioavailable Transition Metals in Particulate Matter Mediate Cardiopulmonary Injury in Healthy and Compromised Animal Models. Environmental Health Perspectives, 105, 1053-1060. http://dx.doi.org/10.1289/ehp.97105s51053

[30] Dreher, K.-L., Jaskot, R.-H., Lehmann, J.-R., Richards, J.-H., McGee, J,-K., Ghio, A.-J. and Costa, D.-L. (1997) Soluble Transition Metals Mediate Residual Oil Fly Ash Induced Acute Lung Injury. Journal of Toxicology and Environmental Health, 50, 285-305. http://dx.doi.org/10.1080/009841097160492

[31] Carvalho, G., Nagato, L., Fagundes Sda, S., Dos Santos, F., Calheiros, A., Malm, O., Bozza, P., Saldiva, P., Faffe, D., Rocco, P., et al. (2014) Time Course of Pulmonary Burden in Mice Exposed to Residual Oil Fly Ash. Frontiers in Physiology, 5, 366.

[32] Borgie, M., Ledoux, F., Verdin, A., Cazier, F., Greige, H., Shirali, P., Courcot, D. and Dagher, Z. (2015) Genotoxic and Epigenotoxic Effects of Fine Particulate Matter from Rural and Urban Sites in Lebanon on Human Bronchial Epithelial Cells. Environmental Research, 136, 352-362. http://dx.doi.org/10.1016/j.envres.2014.10.010

[33] Valavanidis, A., Fiotakis, K. and Vlachogianni, T. (2008) Airborne Particulate Matter and Human Health: Toxicological Assessment and Importance of Size and Composition of Particles for Oxidative Damage and Carcinogenic Mechanisms. Journal of Environmental Science and Health, 26, 339-362. http://dx.doi.org/10.1080/10590500802494538

[34] Gilliland, F., McConnell, R., Peters, J. and Gong, H. (1999) A Theoretical Basis for Investigating Ambient Air Pollution and Children's Respiratory Health. Environmental Health Perspectives, 107, 403-407. http://dx.doi.org/10.1289/ehp.99107s3403 
Scientific Research Publishing (SCIRP) is one of the largest Open Access journal publishers. It is currently publishing more than 200 open access, online, peer-reviewed journals covering a wide range of academic disciplines. SCIRP serves the worldwide academic communities and contributes to the progress and application of science with its publication.

Other selected journals from SCIRP are listed as below. Submit your manuscript to us via either submit@scirp.org or Online Submission Portal.
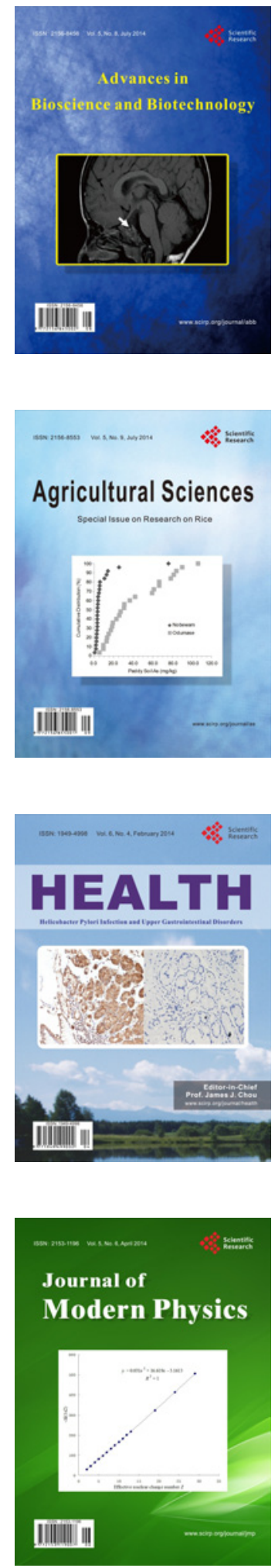
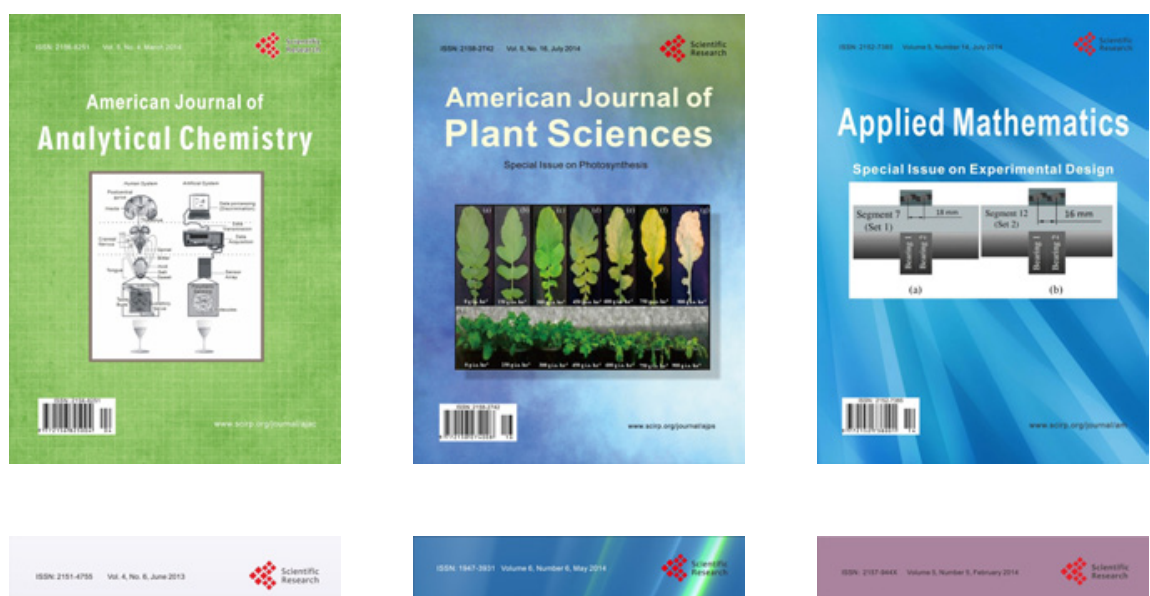

Creative Education
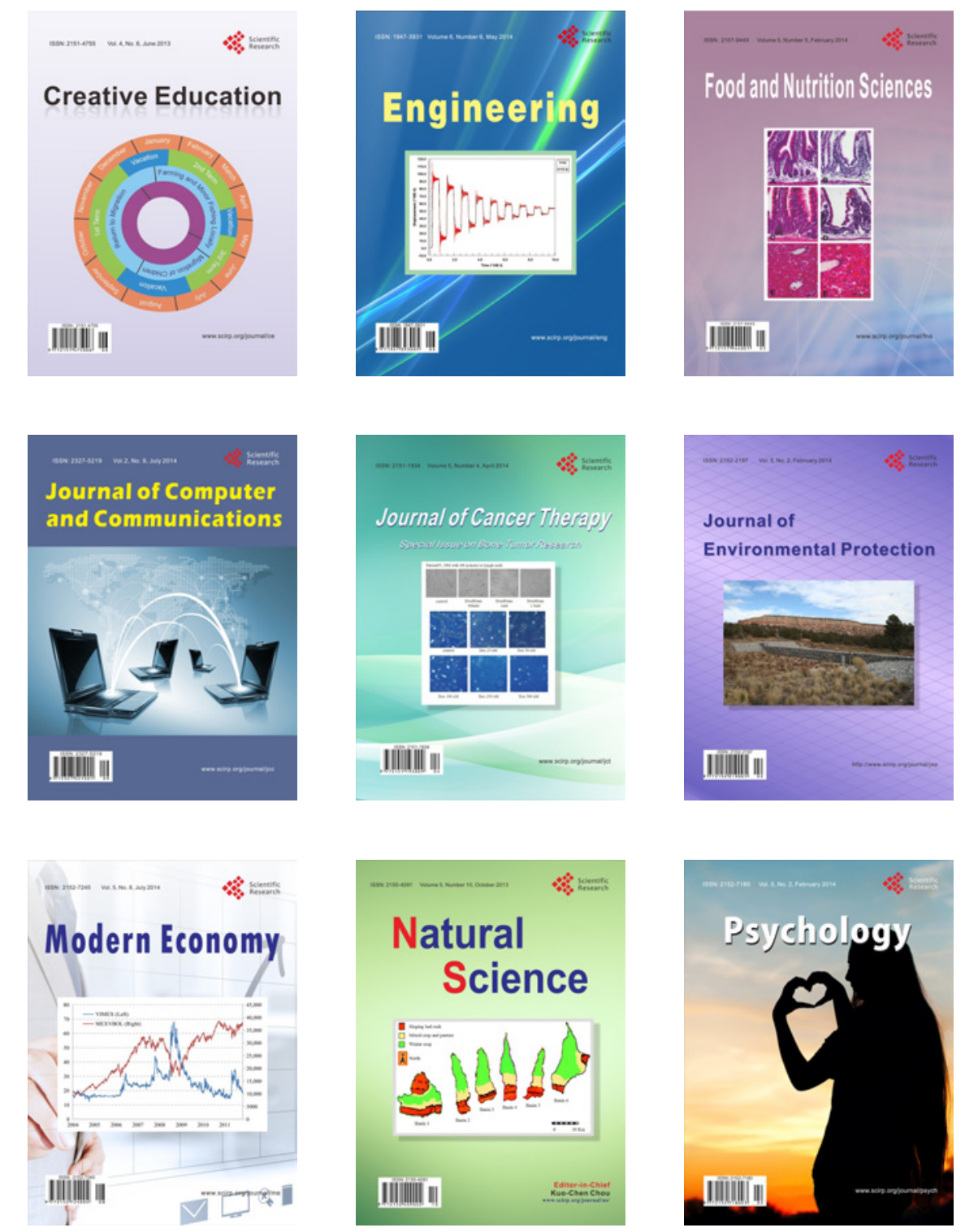